Relations industrielles

Industrial Relations

\title{
Sixth Annual Conference (April 21-22, 1954). Montreal: Industrial Relations Centre, McGill University, 1954, 125 pp., mimeo.
}

\section{Roger Chartier}

Volume 11, numéro 3, juin 1956

URI : https://id.erudit.org/iderudit/1022634ar

DOI : https://doi.org/10.7202/1022634ar

Aller au sommaire du numéro

Éditeur(s)

Département des relations industrielles de l’Université Laval

ISSN

0034-379X (imprimé)

1703-8138 (numérique)

Découvrir la revue

Citer ce compte rendu

Chartier, R. (1956). Compte rendu de [Sixth Annual Conference (April 21-22, 1954). Montreal: Industrial Relations Centre, McGill University, 1954, 125 pp., mimeo.] Relations industrielles / Industrial Relations, 11(3), 221-221.

https://doi.org/10.7202/1022634ar

Tous droits réservés (C Département des relations industrielles de l’Université Laval, 1956
Ce document est protégé par la loi sur le droit d'auteur. L'utilisation des services d’Érudit (y compris la reproduction) est assujettie à sa politique d'utilisation que vous pouvez consulter en ligne.

https://apropos.erudit.org/fr/usagers/politique-dutilisation/ 
bilités sociales et le processus de conciliation; de J. C. Adams et de Eamon Park, sur l'attitude - de la direction et du syndicat, respectivement - à l'égard de la conciliation.

Municipal Labour Relations in Canada. By S. J. Frankel and R. C. Pratt. Montreal: The Industrial Relations Centre of McGill University and Canadian Federation of Mayors and Municipalities, 1954. 87 pp.fl $\$ 2.50$.

Ce petit texte, cartonné et très bien présenté, fait oeuvre de pionnier dans le domaine de la négociation collective sur le plan municipal. Il analyse la croissance du syndicalisme municipal, les problèmes de négociation collective des policiers et des pompiers, la législation provinciale qui régit les relations de travail au niveau municipal, la représentation municipale aux négociations; i! offre des critères logiques de niveaux de salaires; enfin, il aborde le problème de l'arbitrage obligatoire.

Près de 50,000 employés municipaux adhèrent à des syndicats qui négocient avec leur employeur. Ce chiffre, à lui seul, indique déjà l'importance de l'étude de Frankel et Pratt. Les auteurs ont résumé une matière difficile dans un texte clair, concis, critique. Leur étude de l'arbitrage, volontaire ou obligatoire, mérite particulièrement l'attention.

Sixth Annual Conference (April 21-22, 1954). Montreal: Industrial Relations Centre, McGill University, 1954, 125 pp., mimeo.

Pour qui cherche une source compacte et facile d'accès sur les problèmes des agents de maîtrise (contremaîtres, surintendants) dans l'industrie moderne, le. Rapport du 6e Congrès de McGill constitue une réponse partielle. Souligaons d'abord le texte serré, en deux sections, du professeur Kahn. de l'Université du Michigan, sur «Leadership Patterns and Organization Effectiveness». Puis, l'article très original et très stimulant du professeur Neil $W$. Chamberlain, quelque pøu dans la veine du précédent quant à l'obiet - le contremaître - sinon quant à l'« approche ». Se rattachant aux deux textes précités, la conférence du professeur Stagner, de l'Université de l'Illinois, souligne l'impontance des attitudes en relations indus- trielles; elle s'appuie sur les recherches très poussées que le professeur Stagner et son groupe ont effectuées à Illini City, et dont les résultats remplissent deux tomes imposants.

Deux autres conférences, qui font un peu figure de hors-d'oeuvre en dépit de leur valeur autonome, viennent compléter le volume. La première, du professeur Kierans, décrit les \& Full Employment Stresses 》; la seconde, de M. George W. Brooks, un chef syndical, traite des avantages et limitations de la convention collective.

\section{Effective Personnel Selection Procedures. \\ By C. Harold STONE and William E.}

KENDALL. Englewood Cliffs, N.J.:

Prentice-Hall, Inc., 1956. 433 pp.

Both authors are psychologists actively working in the Personnel field, and this shows in the down-to-earthness of their approach and in the step-by-step techniques which are described alongside more lofgty statements of principles and policies. Emphasis, it seems, has been placed on research and evaluation of programs, practices and procedures used in companies.

The book deals with the ways and means of finding people and putting them to work. Over this extravagantly vast array of textbooks discussing with considerable superficialness, doubtless - all the many facets of Personnel Administration, Stone and Kendall's book has the definite advantage of bringing together into one volume all major topics of recruitment, selection and induction.

Part III, on Testing, is especially recommended.

The book, although competent, makes no attempt at sophistication. It is a well-written, well-subdivided textbook of an introductory nature covering quite thoroughly the selection process in Personnel work. Students are likely to find it most useful; practicioners will read it as a good refresher.

\section{Handbook of Industrial Engineering and} Management. Edited by W. Grant Ireson and Eugene L. Grant. Englewood Cliffs, N.J.: Prentice-Hall, Inc., $1955, \quad 1203$ pp. $\$ 12.00$.

Inutile, en quelques lignes, de tenter de rendre justice à ce mammouth aux 